Hugoye: Journal of Syriac Studies, Vol. 18.2, 379-398

(C) 2015 by Beth Mardutho: The Syriac Institute and Gorgias Press

\title{
FORMULAIC PROSE? RHETORIC AND MEANING IN LATE MEDIEVAL SYRIAC MANUSCRIPT COLOPHONS ${ }^{1}$
}

\author{
THOMAS A. CARLSON \\ OKLAHOMA STATE UNIVERSITY
}

\begin{abstract}
The most numerous genre of Syriac texts is the manuscript colophon. Colophons have long been regarded as essential for dating manuscript copies, itself useful for textual criticism. In the past two decades, studies by David Wilmshurst and Heleen Murre-van den Berg have shown the value of colophons for institutional and social history. This paper analyzes the literary characteristics of a corpus of primarily late medieval Eastern Syriac colophons. At the same time, the paper draws on comparative material from Armenian, Western Syriac, and Christian Arabic colophons to identify the breadth of diffusion of scribal practices.

Scholars have focused on each colophon's unique features rather than broad commonalities, and frequently ignore "formulaic" passages. Nevertheless, not all formulas are equivalent. This paper proposes a double classification scheme of literary formulas in colophon texts, one based on degree of fixity and the other based on
\end{abstract}

1 The author acknowledges with gratitude the insightful comments of the anonymous reviewers. Their remarks improved his article, and would have improved it further had not other professional duties hindered him from following all of their useful suggestions. All remaining mistakes are, of course, the author's own. 
diffusion. Some phrases and sentences are repeated verbatim. Other colophon elements tolerate a greater degree of flexibility, allowing substitution of different words or phrases. At the unstable end of "formulas" may be included common tropes or expected sentiments which scribes typically express in the course of their composition. Scribal formulas also have diffusion patterns. Each formula has temporal and geographical dimensions of introduction, spread, and possible abandonment. Some formulas cross linguistic or confessional boundaries, while others do not.

Finally, scholars have identified prose as "formulaic" or "merely rhetorical" in order to dismiss it as meaningless. Nevertheless, scribal choices regarding which formulas to include, and which phrases to include in formulaic structures, have meaning. In contrast to the prevailing scholarly pessimism, this paper argues for, on the one hand, a cautious optimism for interpretations which take into account the conventions of the colophon genre, and on the other hand, a shift of the center of meaning from individual scribes to the community as a whole.

\section{INTRODUCTION}

In late November of 1477, a priest in a village near Mosul finished copying a volume of liturgical poetry, and began to compose a fitting colophon for the conclusion of the work. After praising God for the book's completion and providing the date in the calendar of the "blessed Greeks," he turned to praise the reigning Catholicos-Patriarch of the East, Mar Shem 'on (d. 1497). The catholicos was, according to this priest, "the one holding the spiritual scepter in the Church of Christ and steering her ship among the waves of the world of time, the most holy sanctuary which the Trinity fixed as its voluntary dwelling upon the earth."’2 This superlative praise is only the beginning of an encomium which covers more than a page. Such colophons are abundant in the manuscripts which preserve Syriac texts to the present, yet scholarly tools to understand colophons are largely limited to extracting "the facts" of the composition and discarding the rest. This paper asks the question how scholars should interpret colophons such as this one.

${ }^{2}$ Vat. sir. 186, f. 240 a. 
David Wilmshurst's Ecclesiastical Organisation of the Church of the East, 1318-1913 collected a database of over 2400 dated East Syrian manuscripts. ${ }^{3} \mathrm{~A}$ few database entries represent inscriptions or other kinds of manuscript notes, but the majority of these dates, well over two thousand, are taken from complete or partial colophons. More recent colophons are progressively longer and more numerous than older texts, often running to several whole pages at the end of a manuscript. Wilmshurst's published database only represents East Syrian manuscripts; when one factors in an unknown number of West Syrian colophons as well, it is clear that manuscript colophons comprise by far the most abundant genre of Syriac text. This should not be surprising, since other genres are represented only in some manuscripts, while almost all Syriac manuscripts since late antiquity contain, or at one time contained, a colophon.

The colophon is also frequently the least appreciated of textual genres. Scholars have long regarded the colophon as just so much window dressing around the few reported facts of importance: the date of the copy, perhaps the date of the manuscript from which it was copied, and the location where the copy was made. References to the ecclesiastical hierarchy were analyzed by Wilmshurst, ${ }^{4}$ as were references to patrons by Heleen Murre-van den Berg. ${ }^{5}$ But apart from identifying key facts, the prose which is used to express these details is typically regarded as strictly formulaic, and therefore meaningless. ${ }^{6}$ If the details of copying could simply have been communicated by a bulleted list, it would have suited most modern scholars much better.

The notion that formulaic prose is meaningless receives ample attestation even from leading scholars. Addai Scher, whose catalogues of several Middle Eastern collections before the Sayfo of 1915 are invaluable for textual information, excluded any formulaic

3 David Wilmshurst, The Ecclesiastical Organisation of the Church of the East, 1318-1913, Corpus Scriptorum Christianorum Orientalium, 582; Subsidia 104 (Lovanii: Peeters, 2000), 382-732.

${ }^{4}$ Ibid., 1-370.

${ }^{5}$ Heleen L. Murre-van den Berg, "Generous Devotion: Women in the Church of the East between 1550 and 1850," Hugoye 7, no. 1 (2004): $11-54$.

${ }^{6}$ A few examples of scholars who consider the meaning of scribal formulas will be discussed in the final section of the article. 
phrases. He explained in the introduction to his catalogue for Siirt, "Je dois faire remarquer ici qu'en reproduisant les titres et les clausules des ouvrages, j’ai supprimé les formules banales, comme par exemple, 'Par la vertu de N. S. J. C. nous commençons à écrire tel livre.' - 'Ce livre a été achevé par le très-faible, miserable, pauvre, pécheur... un tel... du temps du Père des Pères, Pasteur des Pasteurs, Père des Orphelins et des Veuves, Fondateur des écoles... Mar un tel..."' Similar sentiments are found among scholars who have dealt with Armenian colophons. Avedis K. Sanjian, who translated sections of Armenian colophons for the reference of Middle Eastern historians, apologized for the limitations of the genre due to its uniformity. ${ }^{8} \mathrm{He}$ described omitted phrases as "stereotyped formulas [which] do not supply any information of historical value." Although he mentioned that Armenian colophons typically begin with a theological prologue, he insisted, "These theological sections are so standardized that they are of little value, even from the standpoint of tracing the historical development of the Armenian theological and Christological position." 10 Even the great manuscript cataloguers of the $19^{\text {th }}$ century, such as William Wright and Eduard Sachau, frequently omitted or paraphrased colophons, or parts of colophons, in order to communicate the essential details. ${ }^{11}$

7 Addai Scher, Catalogue des manuscrits syriaques et arabes conservés dans la bibliothèque épiscopale de Séert (Mosul: Imprimerie des pères dominicains, 1905), 4.

8 Avedis K. Sanjian, trans., Colophons of Armenian Manuscripts, 1301 1480, Harvard Armenian Texts and Studies 2 (Cambridge, Mass.: Harvard University Press, 1969), xii.

${ }^{9}$ Ibid., xiii.

10 Ibid., 7.

${ }^{11}$ For example, Wright transcribed only 73 words of over 200 in the colophon of Cambridge Add. 616, ff. 108b-109a: William Wright and Stanley Arthur Cook, A Catalogue of the Syriac Manuscripts Preserved in the Library of the University of Cambridge (Cambridge: Cambridge University Press, 1901), 2. Sachau similarly reproduced only 35 words of the short colophon (63 words) in Berlin or. quart. 801, f. 48b: Eduard Sachau, Verzeichniss der syrischen Handschriften der königlichen Bibliothek zu Berlin (Berlin: A. Asher, 1899), I:260. Another example of Wright's abbreviation of a colophon is translated by Heleen L. Murre-van den Berg, "I the Weak Scribe', Scribes in the Church of the East in the Ottoman Period," Journal of Eastern Christian Studies 58 (2006): 15. 
The formulaic prose which comprises the bulk of colophons, the largest genre of Syriac literature, challenges not only Syriac scholars but also theories of meaning. How do we come to terms with formulaic prose? And are the formulas simply valueless? If the formulas are truly meaningless, then why were they so widely repeated? The widening adoption of many colophon formulas provides a prima facie reason to treat them seriously. This paper will approach the question of the meaning of the formulaic prose after analyzing more closely the range of phenomena identified as "formulaic" by means of two typologies. The exposition of these typologies was developed with reference to a corpus of over forty complete or partial Eastern Syriac manuscript colophons which the author has transcribed directly or consulted in published full transcriptions, primarily from the fifteenth and sixteenth centuries with a handful earlier and a handful later. The author also consulted a few Western Syriac manuscripts, a few Garshuni and Arabic manuscripts belonging to both the Syriac Orthodox Church and the Church of the East, and over a thousand published fifteenth-century Armenian manuscripts. ${ }^{12}$ Since the mechanisms which drive these typologies are inherent in scribal acts and linguistic choices, however, it is suggested that the method of interpretation proposed here may be much more widely applicable than late medieval Syriac manuscripts.

\section{Classification 1: FIXITY}

Not all formulas are equally formulaic. The first typology I wish to propose for colophon formulas, therefore, is the degree of fixity. Some phrases are found verbatim in many different manuscript colophons. An example of such a fixed formula occurs toward the end of almost every fifteenth-century East Syrian manuscript colophon which is preserved in its entirety: "Blessed be God forever and glorified be his name to generations of generations."13

12 L. S. Xač'ikyan, Tasnbingerord dari hayeren jerhagreri bišatakaranner (Yerevan: Haykakan S. S. H. Gitut'yunneri Akademiayi Hratarakzut'yun, 1955-1967), 3 vols.

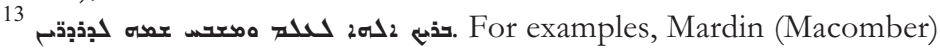
35,16 = HMML CCM 00221, f. 88a; Vat. sir. 186, f. 241b; Princeton Garrett Syr. 22, f. 97b. Manuscripts which I have accessed through the Hill Museum and Manuscript Library are cited with both their local call 
This phrase occurred verbatim in earlier manuscripts as well, such as three dated 1206, 1301, and 1395, ${ }^{14}$ and it is the same in manuscripts as late as the nineteenth century. ${ }^{15}$ Even this formula was not reproduced verbatim in all manuscripts, however. One scribe replaced the word "glorified" (mshabbah) with "established" (msharrar). ${ }^{16}$ The only other deviation from the formula I have observed is the multiplication of the word $d \bar{a}$, as one scribe did thirteen times to fill a whole line. ${ }^{17}$ This doxology is an extreme case of a textual formula included in colophons whose form is nearly invariant.

Other colophon formulas are less fixed. Sometimes there is a template to be followed, but the precise contents of the template can be varied. At this level of fixity, the formula specifies the structure of what is to be said, and perhaps certain elements of that structure are fixed, but other elements are interchangeable and not an essential feature of every instance of the formula. For example, almost all colophons provide the date when the copy was finished, but which calendar(s) were employed vary. ${ }^{18} \mathrm{~A}$ less ubiquitous

number and their HMML library code and source number. CCM stands for the Chaldean Cathedral of Mardin. The sole manuscript I have observed which omits this formula entirely is Paris BN Syr. 369, whose colophon is not fully legible yet evidently lacked the phrase.

14 Cambridge BFBS 446, f. 253a; Diyarbakr (Scher) $91=$ HMML CCM 00419 f. 217b; and Vat. sir. 22, f. 93b, according to Giuseppe Simone Assemani and Stefano Evodio Assemani, Bibliotheca apostolica vaticana codicum manuscriptorum catalogus in tres partes distributus in quarum prima orientales, in altera Graci, in tertia Latini, Italici aliorumque Europaorum idiomatum (Paris: Maissonneuve frères, 1926), II:187.

${ }^{15}$ For example, see Berlin or. quart. 845, f. 180a, which also preserves the phrase in the colophon copied from its fifteenth-century exemplar.

${ }^{16}$ BL Add. 7177, f. 321a.

17 Cambridge Add. 1965, f. 257b. Cambridge Add. 616, f. 109a, included eleven occurrences of darr.

${ }^{18}$ Françoise Briquel-Chatonnet, "Le temps du copiste: Notations chronologiques dans les colophons de manuscrits syriaques," in ProcheOrient Ancien. Temps vécu, temps pensé, ed. Françoise Briquel-Chatonnet and Hélène Lozachmeur, Antiquités Sémitiques 3 (Paris: Jean Maissonneuve, 1998), 197-210; Sebastian P. Brock, "The Use of Hijra Dating in Syriac Manuscripts: A Preliminary Investigation," in Redefining Christian Identity: Cultural Interaction in the Middle East since the Rise of Islam, ed. Jan J. van 
formula of this level of fixity is the common trope comparing the scribe's completion of his task to a ship reaching harbor: as Sebastian Brock demonstrated, the precise words used in this metaphor vary, from alternate terms for "sailor" to heightened drama of storms at sea, though the basic structure is often somewhat standard. ${ }^{19}$

A more extended example of a partially fixed formula is the manner in which most East Syrian colophons in the past millennium identify the reigning patriarch. This is usually accomplished by stating that the book was written "in the days of ... Mar So-and-so the Catholicos-Patriarch of the East."'20 Before the name, it is obligatory to insert positive descriptions of this catholicos, though the precise selection of phrases is left to the scribe. Certain phrases occur in multiple manuscripts, such "the father of fathers" and "the chief of the shepherds," 21 but most manuscripts insert praises here which are unique to that scribe or that colophon. ${ }^{22}$ In most colophons, a prayer for the patriarch will follow the name. While certain themes recur among these prayers,

Ginkel, Heleen L. Murre-van den Berg, and Theo M. van Lint, Orientalia Lovaniensia Analecta 134 (Leuven: Uitgeverij Peeters, 2004), 275-90.

19 Sebastian P. Brock, "The Scribe Reaches Harbour," Byzantinische Forschungen 21 (1995): 198-201.

${ }^{20}$ E.g. Paris BN Syr. 184, f. 125b. There are some variations even among these skeletal elements, as the word "Patriarch" might be omitted or "of the East" might be enlarged upon. An example of the former is Cambridge BFBS 446, f. 252b; an example of the latter is Mardin (Macomber) 35,16 = HMML CCM 00221, ff. 88a, where the Catholicos is

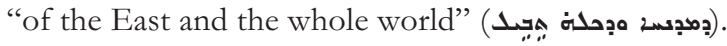

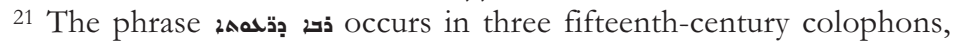

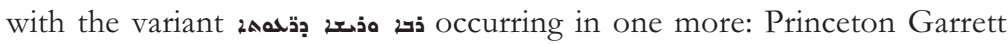
Syr. 22, f. 96b; BL Add. 7177, f. 321a; Berlin Sachau 167, f. 139a; BL Add.

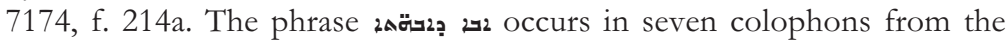
fifteenth century: the four just cited, and also Vat. sir. 186, f. 240a; Paris BN 369, f. 106a; and St. Petersburg Nat. Lib. Syr. 33, f. 316a, this last according to Isho'dad of Merv, The Commentaries of Isho'dad of Merv, Bishop of Hadatha (c. 850 A.D.) in Syriac and English, ed. Margaret Dunlop Smith Gibson (Cambridge: Cambridge University Press, 1911), V, part 1:179.

22 For example, of the colophons I have consulted, only Cambridge BFBS 446, f. 252b, describes the patriarch as the "universal father" (202). Only Vat. sir. 186, f. 240b, praises the patriarch as "possessing

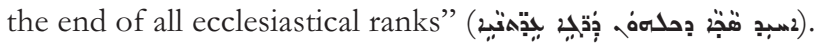


such as long life, it is rare to find two manuscripts where this prayer is identical. ${ }^{23}$ Thus the template for naming the reigning catholicos-patriarch has a certain structure, some elements of which are nearly fixed while others allow wider freedom of expression.

On a larger level than templates which structure particular sentences, one may think of modules from which the entire colophon is constructed. Many colophons will contain paragraphs which report the date of completion, the location of the copying, the reigning catholicos-patriarch and perhaps the bishop, the scribe's identity, and if relevant the identity of the patron or recipient of the manuscript. ${ }^{24}$ Additional modules do not identify information about the copying process, but fulfill other functions, such as the curse uttered against "whomever does not love the Lord Jesus Christ," the request of the reader's indulgence for any errors discovered, or the praise of God for his help bringing the manuscript to completion. In some colophons, these modules are distinguished by alternating red and black ink. ${ }^{25}$ By comparison with Armenian colophons, which typically identify the secular ruler whether Christian or Muslim, it is striking that Syriac colophons

23 Among fifteenth-century manuscripts, the prayer for the catholicos is identical only between Vat. sir. 186, ff. 204b-241a (dated 29 November 1789 A.G./1477), and BL Or. 4399, f. 579a (dated 1800 A.G./1489), but in this case the unusually large section of praise for the patriarch was copied verbatim in both manuscripts, suggesting the later manuscript had access to the former, or to a common source.

${ }^{24}$ Murre-van den Berg had proposed a two-module structure for East Syrian colophons of the Ottoman period, in which the former part begins rwith or a similar phrase and includes the date, while the latter part begins with a form of the verb and includes the place of writing and the scribe's name and place of writing: Murre-van den Berg, "I the Weak Scribe," 14. The formulas which introduce modules vary more widely than Murre-van den Berg indicates, however, and the date does not always precede the other information. For example, in a manuscript dated 1870 A.G. / 1559, both the date and the place of

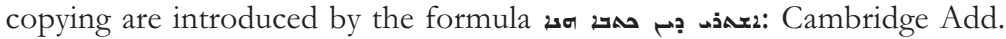
1988, f. 166b. An earlier colophon dated 1517 A.G. / 1206 mentioned the place of copying before mentioning the date: Cambridge BFBS, ff. 225a.

${ }^{25}$ For example, Cambridge BFBS 446, ff. 252a-253a. 
only very rarely refer to a Muslim ruler. ${ }^{26}$ These modules may occur in varying orders in different colophons, and each one has its own level of formulaic fixedness. Some modules may be omitted while keeping the others intact. At the highest level, when East Syrian scribes sat down to compose multi-page colophons, they probably thought at the level of the module, and then filled in each paragraph.

At the loosest end of what might be termed a "formula," there are conventional sentiments which do not necessarily share any words in common. Thus it was necessary to open the colophon ascribing the completion of the manuscript to divine help. Some ways of expressing this were shared between scribes and became relatively common; almost half of the colophons I examined between 1206 and 1559 state that the manuscript was completed

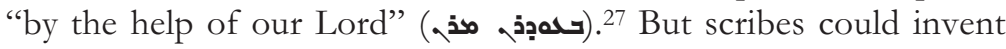
new ways of expressing their gratitude to fulfill the function: an unnamed scribe in 1461 ascribed the completion of the manuscript to "the help of the command of divine grace and the power of the assistance of fatherly care." 28 At greater length, it was almost universally necessary for scribes to express their unworthiness, but there was no consistent template for doing so. Certain words or concepts occurred frequently, such as "sinner" (سדال) and "weak" (مسكل2), but no particular phrases occur in more than a few manuscripts. Medieval scribes commonly asserted their unworthiness of their ecclesiastical ranks or the incongruity between those ranks and their actions, but similarities of sentiment bridge the gap between widely varying expressions. East Syrian scribes enjoyed a fair degree of latitude in how best to express their sinfulness and petition the reader's prayers.

One final category of formula does not easily fit on the spectrum of fixity, but might be termed a formula of process. By

26 The only fifteenth-century example I have found of a colophon naming a reigning Muslim is BL Add. 7177, f. 321a, dated 1795 A.G./1484. Vat. sir. 186, f. 241b, mentions the death of the Türkmen ruler Uzun Hasan in a poem appended by the scribe after his colophon dated 29 November 1789 A. G. / 1477.

27 For a few examples, Cambridge BFBS 446, f. 252a; Diyarbakr (Scher) 91 = HMML CCM 00419, f. 271a; and Paris BN Syr. 345, f. 220a.

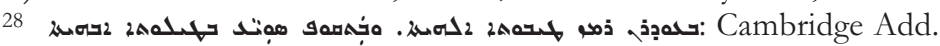
616, f. 108 b. 
the late medieval period, East Syrian colophons' module for identifying the scribe developed a religious contradiction. On the one hand, scribes asked for the reader's prayers for their sins and those of their ancestors. On the other, an increasingly common self-deprecatory formula stated that the scribe "is not worthy for his name to be mentioned." 29 Here we have a conflict: if the scribe is not named, how would the reader know for whom to pray? This tension resulted in various solutions. The most common solution was simply for scribes to include their names anyway, and some satisfied their need for rhetorical humility by appealing to the reader's desire to know: "but if you want to know his name, it is..." 30 A few scribes did simply omit their name, leaving a colophon which is strictly anonymous. ${ }^{31}$ But more computationally adept scribes developed a way to communicate their name without writing it in the book.

Some scribes took to encoding their names using the numeric values of Syriac letters in order to circumvent the religious tension of their colophons. In other words, these scribes replaced each letter of their name in order with the word representing its numerical value. Thus "forty, sixty, seventy, six, four" encodes the name Mas'ùd, since the Syriac letter mim has the value of forty, semkath the value of sixty, and so forth.32 For extra credit, one sixteenth-century scribe even used a double encoding, applying the numerical encoding to the letters of the names of the letters of his name: in a colophon dated 1859 A. G. / 1548, the scribe 'İsā first encoded his name in number words ("seventy, ten, sixty, one" representing (20), and then he wrote down a second string of number words ("seventy and one; ten and six and four; sixty and

${ }^{29}$ For a few examples of the sentiment, see Paris BN Syr. 184, f. 125a; Vat. sir. 176, f. 128b; Mardin (Scher) $30=$ HMML CCM 00310, f. 205a. Although the sentiment became increasingly common, it never became universal in the late medieval period. For example, two colophons from 1849 A.G. / 1538 make no mention of the scribe's unworthiness for his name to be mentioned: Vat. sir. 83, ff. 502b-503a, and Berlin or. fol. 620, f. 400b.

${ }^{30}$ For examples, Paris BN Syr. 184, f. 125a; BL Or. 4399, f. 376a; and Paris BN Syr. 345, f. 220a.

31 Cambridge Add. 616, f. 108b-109a, and Berlin or. quart. 801, f. $48 \mathrm{~b}$.

32 Paris BN Syr. 184, f. 125a. 
forty and twenty and four-hundred; one and thirty and eighty")

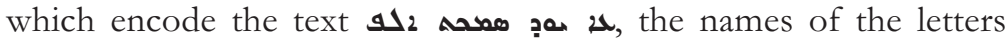
which spell out his name. ${ }^{33}$ He used the same double encoding of his name in another colophon two years later, but then, apparently worried that readers would not do the arithmetic, he spelled out his name in unencoded, but unconnected, Syriac letters. ${ }^{34}$ This encoding slightly qualifies Murre-van den Berg's assertion that Syriac scribes "freely give their names." 35 Rather, most scribes communicated their names to readers, but many did so in ways which also recognized the spiritual dangers involved.

Of course, the spectrum of expressive fixity continues past conventional sentiment into fully non-formulaic prose. By breaking up the different expressions which comprise the colophon along an axis of fixity, it becomes obvious that not every part of a colophon is equally stereotyped. Scher's enumeration of formulaic phrases found in a typical colophon does not represent every East Syrian colophon, indeed not even most East Syrian colophons. ${ }^{36}$ In order to assess the meaning of any given expression in a colophon, it is essential to know the degree of fixedness. But since the degree of fixedness for any given expression will also vary over time and across space, we must also consider the nature of the formula's diffusion.

\section{Classification 2: Diffusion}

Although the detractors of formulaic prose complain that it is ahistorical, in fact even colophon formulas are not timeless features of scribal practice. Instead, different formulas have different processes of diffusion from an initial formulation. These diffusion processes have multiple aspects, including geographic, confessional, and linguistic dimensions in addition to the temporal. The fixity of a formula can also vary over the process of diffusion, as a particular form gets canonized to the exclusion of others or new variations are introduced. To understand the significance of a scribal formula

\footnotetext{
33 Mingana Syr. 421, f. 140a-b.

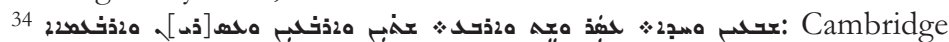
Add. 1983, f. 181b. Curiously, he failed to give the encoding of the final aleph in his name in the latter colophon.

35 Murre-van den Berg, "I the Weak Scribe," 15.

36 Scher, Catalogue de Séert, 4. 
in any given colophon, it is important to understand where in the landscape of the formula's diffusion the specific colophon was composed.

The most obvious dimension of a formula's diffusion is temporal. ${ }^{37}$ The formula was first composed as a new phrase, or adapted in a new direction from an older formula, at some point in time by a particular scribe. Perhaps that scribe continued to use that phrase, either in a fixed form or with certain degrees of variation, and other scribes adopted the expression. Some formulas fall out of use, while others expand to become universal within a certain scribal tradition and perhaps continue today. Although the haphazard preservation of manuscript colophons typically precludes definitive pronouncements regarding the first invention of a formula, collecting all surviving examples sometimes allows certain conclusions to be reached. For example, Sebastian Brock recorded eight different ways of describing manuscript dates according to the hijri calendar according to eleven colophons dated before $900 \mathrm{CE}$. The first instance cited by him was also the most verbose, almost as if the scribe needed to explain the unfamiliar dating system used, whereas by the ninth century the terse phrases used to identify the calendar suggest familiarity. ${ }^{38}$ The development of a small number of fixed phrases to identify this calendar shows how seemingly interchangeable colophon formulas can have different temporal distributions, and the fact that one of those phrases ("of the mhaggray $\vec{e}$ ") is not attested after the ninth century shows not only the temporal dimension of formula development, but also the disappearance of certain formulas.

Language boundaries typically delimit scribal traditions, but a few scribal formulas even spread beyond the bounds of their original language. For example, the East Syrian scribes often refer to the catholicos-patriarch as "the Father of fathers" (2Аت̈コ2 and an Arabic calque occurs in Syrian Orthodox Garshuni manuscripts dated 1526 and $1797 .{ }^{39}$ Formulas also crossed between Syriac and Armenian scribal traditions. Many medieval scribes

${ }^{37}$ In her study of formulaic speech, Alison Wray likewise stressed the ways in which particular formulas change dynamically over time: Alison Wray, Formulaic Language and the Lexicon (Cambridge: Cambridge University Press, 2002), 101.

38 Brock, "Hijra Dating," 278.

39 Mingana Syr. 271, f. 220b; Mingana Syr. 460, f. 10 b. 
indicated their ecclesiastical ranks while disclaiming their worthiness: one might claim to be a priest "in name, but in actions far from it." 40 These clerics were not claiming that they failed to celebrate the liturgy, but rather, that their lifestyle was insufficiently holy to reflect the godly character which should be expected of clergy. The same conventional sentiment is expressed in medieval Armenian colophons by prefacing an ecclesiastical title with unuunuinu\& ("falsely-named"). ${ }^{41}$ In a colophon dated 1810 A.G. / 1499, one Syriac scribe formulated the difference between ecclesiastical title and actions by saying he is "by name a priest and not by actions of righteousness"; a slightly earlier Armenian colophon likewise identifies the scribe as a priest "by name and not by deeds." 42 In this case, it is unclear when the formula was invented, or in which language, but even if it existed in various Middle Eastern languages since late antiquity, it was first used by a single scribe in one language and subsequently was used, by the same scribe or by others, in other languages. It is not surprising for language boundaries to limit the diffusion of formulas, given that scribes typically operated within linguistically defined traditions. But some formulas passed over these hurdles to spread in multiple linguistic settings.

Confessional boundaries also often circumscribe the diffusion of scribal formulas, although a shared language may make these boundaries more easily crossed. The formula "to God be glory and upon us be his mercies forever" occurs in an East Syrian manuscript dated 1795 A.G. / 1484 and a Syrian Orthodox manuscript almost a century later, dated 1884 A.G. / 1573.43 The Arabic expression that a manuscript was completed "by God's help" was used by both East Syrian and West Syrian scribes in the

40 For example, Vat. sir. 22, f. 93b, according to Assemani and Assemani, Bibliotheca apostolica vaticana codicum manuscriptorum catalogus, II:187.

41 For examples of the use of untunu\{untu, see Xačikyan, Tasnhingerord, III:38, 81, 88.

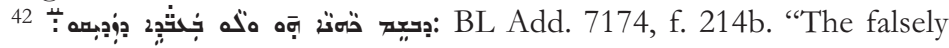
named presbyter, which I am called in name and not by deeds"

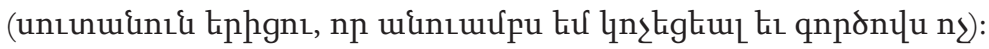

43 20د5 20: BL Add. 7177, f. 320b; Mingana Syr. 1, f. 194a. 
sixteenth century. ${ }^{44}$ The conventional sentiment of scribal unworthiness was expressed in similar terms by Syrian Orthodox scribes as well as East Syrian scribes. And a Syrian Orthodox priest named Ephrem in Dayr al-Za farān in 1885 A. G. / 1574 described himself as "in name a monk and priest and in action far from his name and title," using another formulation familiar to East Syrian scribes. ${ }^{45}$ The fact that medieval texts tended to circulate primarily within ecclesiastical circles limited scribes' exposure to formulas of other denominations, and a few formulas presume specific confessional allegiances. Nevertheless, some formulas were shared across confessional boundaries.

Less obvious to scholars, perhaps, is the geographic dimension of the diffusion of scribal formulas. A formula was first invented by a particular scribe in a particular place, and later spread to other places, either due to the movement of scribes or due to the movement of books in whose colophons the formula may be found. Some variant on the phrase "chief of shepherds" is given as a patriarchal title in five fifteenth-century manuscripts, of which four are from the Mosul plain and the place of origin of the fifth is unknown. ${ }^{46}$ Unless it is a trick of the paucity of surviving manuscripts, it appears that this formula had only a regional currency in the fifteenth century, not occurring in East Syrian manuscripts of that period from TTùr 'Abdīn, Nisibis, Hakkari, or Shanqlabad outside Erbil. In the first half of the sixteenth century, the title also appeared in two colophons from the regions of Siirt and Gāzartā, the latter colophon composed by a scribe from Alqōsh, closer to Mosul. ${ }^{47}$ The phrase did not originate in the

44 بعون الله : Mingana Syr. 434, f. 153a; Mingana Syr. 201, f. 149b.

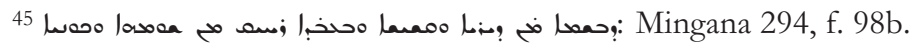

${ }^{46}$ Vat. sir. 186, f. 240a (Grịhā near Mosul); Princeton Garrett Syr. 22, f. 97a (Mosul); BL Add. 7177, f. 321a (Mosul); Berlin Sachau 167, f. 139a (unknown); and BL Add. 7174, f. 214a (Tal Zqīpā). Although the colophon of the Mosul manuscript BL Or. 4399 is damaged, its section in praise of the catholicos is copied from Vat. sir. 186, so its original colophon would likely have contained the phrase.

${ }^{47}$ Paris BN Syr. 345, f. 220b (Bōrb near Siirt) and BL Add. 7178, f. 465a (Gāzartā). The colophon of BL Add. 7178 does not mention that the scribe was from Alqōsh, but this particularly prolific scribe is known from several other colophons which indicate his family origin: Vat. sir. 83, f. 503a; Wilmshurst, Ecclesiastical Organisation, 114. The origin of the scribe in 
fifteenth-century Mosul plain, however: it had already been used in at least one colophon from Malabar dated 1612 A.G. / 1301.48 The selective nature of the surviving evidence may render impossible any attempt to trace precisely the trajectory of geographic diffusion of formulas which became universal, but it may permit certain suggestions of general patterns.

Scribal formulas do not exist in abstraction, but are used in a real world, spread over time, geography, languages, and confessions. Each scribal formula has its own diffusion process, which means that no particular formula can be presumed universal. Even for formulas which were repeated verbatim at a later period, they were perhaps not so completely fixed in an earlier century. An awareness of these diffusion processes helps us understand the choices made by the scribe, which affects our assessment of any given formula's meaning.

\section{WHAT DO FORMULAS MEAN?}

With a clearer understanding of the different types and diffusion patterns of formulas, we are in a better position to assess the meanings of formulaic prose. Scholars such as Addai Scher and Avedis Sanjian have regarded the rhetorical filigree of colophons as merely formulaic, and therefore meaningless. But in fact, the choices made by scribes in the composition of a colophon point to specific meanings for textual formulas, when the text is read in the context of the range of other colophons.

A familiarity with formulaic prose will enable scholars to identify which colophon elements are not in fact formulaic. For example, while it is conventional to praise the current patriarch, the praise accorded to the patriarch in the example which opens this article, by a scribe near Mosul in late 1477, exceeds all bounds of convention. The scribe described the patriarch as

the one holding the spiritual scepter in the Church of Christ and steering her ship among the waves of the world of time, the most holy sanctuary which the Trinity fixed as its voluntary dwelling upon the earth, the illuminating

the Siirt region is not specified, so it is unclear if he had any connection to the Mosul plain.

48 Vat. sir. 22, f. 93b, according to Assemani and Assemani, Bibliotheca apostolice vaticana codicum manuscriptorum catalogus, II:187. 
Presence (Shekinah) which the eternal Being made a temple for the overshadowing of the power of its might, the spiritual pillar which gives light and guides before his saved one, Israel. 49

While a scholar might be tempted to describe this praise as "formulaic," in fact I have found no parallel to any of these phrases in the other colophons I have examined. A colophon from a few years later describes the catholicos-patriarch as "holding the scepter of high priesthood," but that is the closest parallel I have found for this portion of the colophon, and it does not begin to scratch the surface of the 1477 encomium. ${ }^{50}$ Knowing which phrases are in fact formulaic may allow scholars to evaluate the evidence more accurately. In this case, the excessive praise may seek to assuage insecurities about the legitimacy of a patriarch who was probably newly elected after a long hiatus in the patriarchal line. ${ }^{51}$

But some prose is in fact formulaic. Although most scholars have discounted such prose as meaningless, a few have hinted at alternate approaches. Françoise Briquel-Chatonnet suggested that the choice of calendars used by Syriac scribes to date their colophons “n'est pas neutre: le choix d'une ère est une manière de penser le temps par rapport à un point fixe qui sert de référence et

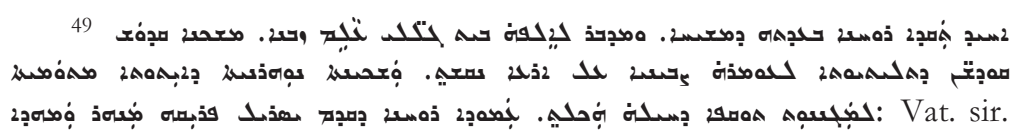
186, f. 240a.

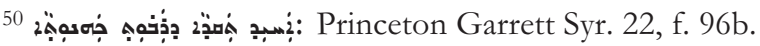

51 The fifteenth-century succession of the catholicos-patriarchs of the Church of the East is notoriously difficult to pin down: Heleen L. Murrevan den Berg, "The Patriarchs of the Church of the East from the Fifteenth to Eighteenth Centuries," Hugoye 2, no. 2 (1999): 240. Only one surviving colophon between 1448 and 1476 names any catholicos, and that is a Catholicos Ëlīyā mentioned in 1463: Mardin (Macomber) 35,16= HMML CCM 00221, f. 88a. Ëlìyā was not named in a 1465 colophon, suggesting either that Ēliyā's reign was brief or that it was rejected as illegitimate by some scribes. The 1477 colophon is the first one since Ëlìà's 1463 appearance to mention a catholicos, and the fact that a 1476 colophon (Vat. sir. 176, f. 128a) mentioned no catholicos again suggests either that Shem 'ōn "IV" was not recognized in all quarters or that he had not been long in office. 
témoignage d'un véritable choix culturel." 52 Thus even a detail as seemingly banal as a calendrical identifier can indicate how a culture chooses to think of its past. Heleen Murre-van den Berg attempted to synthesize the spiritual content of the formulas of Ottoman-era East Syrian colophons to delineate "the religious world of the scribes." 53 She noted, however, that despite diversity in textual detail, "the basic elements [of colophons] are shared by all scribes and should therefore be treated as reflecting their common training and (religious) tradition, not their individual opinions or beliefs... The variety between the colophons seems to be guided by stylistic preferences, much more so than by individual opinions on religious or secular matters." 54 Both of these approaches therefore speak of meaning for the community rather than the individual, and regard the colophon as an expression of broad-based cultural values which may, or may not, be shared by any individual scribe.

A different way to ask the question of meaning is to address it as an issue of difference: what difference does a particular formula make? As we saw in the first typology, different formulas have different degrees of fixity, and so some formulas may occur in different forms. To the degree that a formula is not verbatim, the components that get swapped in are meaningful. In his list of conventional formulas in praise of a catholicos-patriarch, Addai Scher included the phrase "the founder of schools." 55 But such a praise is absent from all colophons I have examined between 1350 and 1550; instead, late medieval scribes praised the patriarch for other things, such as diligence and holiness. The sole mention of schools which I have found in a late medieval colophon praises, not the patriarch, but a priest named 'Īsā b. Hasan of Tal Zqịpā for his diligence in "the occupation of churches, the copying of books, and the teaching of schools." ${ }^{6}$ From this we might conclude that schools were not being founded in the late medieval period, or that the patriarchs were not involved in the process, or that other patriarchal roles were considered more laudable. Although many

52 Briquel-Chatonnet, "Le temps du copiste," 200.

${ }^{53}$ Murre-van den Berg, "II the Weak Scribe," 20-25.

${ }^{54}$ Ibid., 21.

55 Scher, Catalogue de Séert, 4.

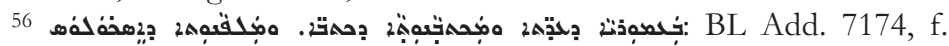
206a. 
scribal praises of the catholicos were already conventional, it was necessary to pick some with which to praise the current office holder. The selection seems to have been largely up to the individual scribe and could indicate particular values of that copyist.

Even if a formula was completely fixed and repeated verbatim, there remains the potential difference of its presence or absence, and if the formula is nearly ubiquitous, then its absence may be more revealing than its presence. One example of a pungent absence of a scribal formula is when a colophon does not include the customary identification of the catholicos-patriarch. In the fifteenth century, a period for which the succession of the patriarchate is unclear, an absence of a reference to a catholicos may perhaps indicate that the office was vacant. But in a colophon dated 1859 A.G. / 1548, the scribe 'İsā b. Abraham b. Hormizd of the village of $\overline{\mathrm{O}} \mathrm{z}$ composed a colophon without once mentioning the current catholicos, Shem 'ōn Bar Māmā. ${ }^{77}$ Five years later, this catholicos faced open rebellion as the monk John Sūlāqā from the monastery of Rabban Hormizd was consecrated as "Patriarch of Babylon" by the Pope in Rome. ${ }^{58}$ The missing colophon formula is a clue that already in 1548 some were disputing Shem 'ōn Bar Māmā’s legitimacy.

But even fixed scribal formulas use words, and those words provide a semantic context. ${ }^{59}$ As Murre-van den Berg pointed out, opening a colophon with the formula, "This book was completed by the help of God," and closing it with the benediction, "Blessed be God forever," as almost all scribes did, establishes a theological

${ }^{57}$ Mingana Syr. 421, ff. 140a-b. Another colophon by the same scribe two years later does not mention the catholicos, but it is incompletely preserved, so we cannot be certain that it did not originally mention the patriarch: Cambridge Add. 1983, ff. 183a-b. It seems likely, however, that the same scribe in both colophons omitted any reference to the reigning catholicos-patriarch.

58 Giuseppe Simone Assemani, Bibliotheca Orientalis Clementino-Vaticana (Rome: Typis Sacrae Congregationis de Propaganda Fide, 1719), I:523-30.

${ }^{59}$ Here I posit a distinction between the formulaic speech studied by Wray, where a word phrase may be learned whole and used without conscious analysis of its constituent parts, and the slower and more deliberate act of writing, especially with premodern pens and ink: Wray, Formulaic Language, 4, 33. 
context for the colophon itself. ${ }^{60}$ This theological context is maintained throughout the colophon by interspersed prayers for God to bless the ecclesiastical hierarchy and to protect the place where the manuscript was copied, as well as by references to the calendar of the "blessed Greeks" or even "blessed Arabs," appeals to the intercession of a patron saint, and requests for the reader to pray for the sins of the scribe. This rhetoric constructs a network of invoked ideas within a communal religious framework.

Did scribes believe these ideas? No use of language is simply a reflection of the beliefs of the language user; instead, we must assess the uses to which various kinds of language may be put. This pragmatic dimension is no different for formulaic language than for other kinds of language. ${ }^{61}$ A copyist might use the theological rhetoric of his colophon in order to convince readers of his piety, and perhaps thereby secure a reader's prayers for himself or at least enhance the prestige of his copy. For those scribes who are religious, the formulas that they use in composing the colophon would direct their beliefs in certain directions rather than others. While some theological formulas are more specifically Christian than others, including a standard curse upon "all who do not love our Lord Jesus Christ," 62 none of the late medieval East Syrian colophon formulas express specifically Jewish, Manichaean, or Muslim ideas. So while, as Murre-van den Berg warned, the level of any individual scribe's faith may not be revealed through the formulas chosen, the direction of their communal faith is indicated by the rhetorical choices made. ${ }^{63}$

The colophon is the most numerous genre of Syriac texts, composed for nearly every Syriac manuscript. The scribes who composed these manuscripts have often been regarded as mere copyists, but at the end of the task they took up the role of authors in their own right to compose a new text, their new manuscript's colophon. Scholars have long resisted this viewpoint due to the "merely" formulaic character of such texts. Scribal formulas are

${ }^{60}$ Murre-van den Berg, "II the Weak Scribe," 21-22.

61 Wray likewise emphasized the need for pragmatics in assessing formulaic speech: Wray, Formulaic Language, 58.

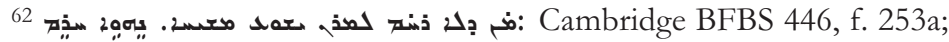
Cambridge Add. 616, f. 109a; Vat. sir. 186, f. 241 b; Princeton Garrett Syr. 22, f. $97 \mathrm{~b}$.

${ }^{63}$ Murre-van den Berg, "II the Weak Scribe," 21. 
often presented as less meaningful than newly composed phrases, because they do not require selecting the individual words in every case. In fact, the formulaic character of most colophons has been greatly overstated, and even formulas do require scribes to make choices: which modules to include, how to express the required sentiments, which phrases to insert into the key spots, and even which fixed formulas to include or exclude. In order to assess these choices within the context of available options, a particular formula must be located on the scale of fixity and its particular stage of diffusion at the time the scribe used it. Even if some formulas may have been used by individual scribes who did not believe them, they were used to accomplish specific goals within the community and generally indicate the range of ideas acceptable for expression. The potential for formulaic prose not merely to communicate, but also to resonate or alternately to be trite in particular communal contexts, allows scribal formulas to make language not less but more flexible in what and how much it means. 